\title{
Strategi Penerapan Kota Kompak Berdasarkan Pola Urban Compactness di Kota Bekasi
}

\author{
Arini Natasya Aisyah dan Putu Gede Ariastita \\ Perencanaan Wilayah dan Kota, Fakultas Teknik Sipil dan Perencanaan, Institut Teknologi Sepuluh \\ Nopember (ITS) \\ e-mail: ariastita@gmail.com
}

\begin{abstract}
Abstrak-Kota Bekasi sebagai Kota besar yang terletak di konstalasi metropolitan Jabodetabek belum diterapkan konsep pembangunan kota kompak secara komprehensif. Penelitian ini bertujuan untuk Merumuskan Strategi Penerapan Kota Kompak Berdasarkan Pola Urban Compactness di Kota Bekasi. Penelitian ini menggunakan analisis regresi linear berganda dalam menentukan faktor faktor kekompakan Kota Bekasi, dari faktor faktor tersebut ditentukan tingkat kekompakannya menggunakan metode klasifikasi sturgess, kemudian tingkat kekompakan tersebut dipolakan untuk mengetahui pola spasial kekompakan sehingga dapat dirumuskan strategi penerapan kota kompak berdasarkan pola spasial dari tingkatan faktor faktor yang telah diperoleh. Hasil yang diperoleh dalam penelitian ini adalah terdapat klasifikasi lima kluster kekompakan di Kota Bekasi yaitu; Kluster I merupakan kluster yang struktur kota nya telah mencerminkan kompak, Kluster II merupakan kluster yang telah memiliki struktur kompak dengan konsep Mixed Use Zoning dikarenakan adanya jalur KKOP, Kluster III merupakan kluster yang mempunyai pondasi untuk membentuk struktur kompak namun belum ada perencanaan yang matang menuju struktur kompak, Kluster IV merupakan kluster yang mempunyai ciri kekompakan namun belum meiliki pondasi kota kompak, dan Kluster V merupakan Kluster dengan kecenderungan sprawl dimana kepadatan permukiman termasuk rendah dan penggunaan lahan yang belum terkonsentrasi secara efisien dengan konsep yang mendekati kompak.
\end{abstract}

Kata Kunci_Compact City, Urban Compactness, Pola Spasial.

\section{PENDAHULUAN}

$\mathrm{K}$ ONSEP kota kompak merupakan perbaikan dari konsep kota yang berkembang secara sporadis atau urban sprawl [1]. Konsep kota kompak (compact city) telah diterapkan sebagai revitalisasi urban sprawl pada beberapa negara maju. Urban compactness dapat dijadikan ukuran kekompakan suatu kota, indicator-indikator pengukuran urban compactness tersebut kedalam tiga dimensi, yaitu kepadatan, fungsi campuran, dan intensifikasi, aspek kepadatan berkaitan dengan tingkat kepadatan penduduk, kepadatan lapangan kerja, kepadatan terbangun, kepadatan sub-pusat, serta kepadatan perumahan, aspek fungsi campuran terkait dengan penyediaan dan penyebaran infrastruktur, perubahan guna lahan, serta aspek intesifikasi meliputi tingkat pertumbuhan penduduk, pertumbuhan pembangunan, pertumbuhan kepadatan pembangunan baru, serta pertumbuhan kepadatan sub pusat [2].

Dampak fenomena urban sprawl Jabodetabek sangat mempengaruhi dinamika Kota Bekasi. Dinamika di Bekasi sama sekali tidak direncanakan dengan baik dan matang. Kota Bekasi telah mengalami gejala kekompakan hal ini dapat dilihat dari aspek kepadatan dimana Kota Bekasi merupakan kota terpadat keempat di Indonesia [3]. Aspek fungsi campuran dapat dilihat dari ketersediaan fasilitas dan utilitas kota Bekasi yang telah mandiri [4]. Serta aspek intensifikasi, Kota Bekasi merupakan wilayah Bodetabek dengan pertumbuhan paling cepat di antara wilayah lainnya, kenaikan harga lahan dengan didorongnya pertumbuhan penduduk yang pesat [1].

Dari gejala kekompakan yang dialami Kota Bekasi tersebut mendorong pembangunan berkonsep permukiman kompak di Kota Bekasi namun pembangunan tersebut masih bersifat sporadis dan belum mempunyai penerapan secara komprehensif untuk keseluruhan pembangunan kota kompak di Kota Bekasi. Dari uraian tersebut diperlukan pengukuran kekompakan Kota Bekasi yang disesuaikan dengan karakteristik wilayah Kota Bekasi untuk mengetahui strategi apa yang sesuai untuk penerapan kota kompak.

\section{METODE PENELITIAN}

\section{A. Metode Pengumpulan Data}

Pengumpulan data dalam penelitian ini dilakukan melalui metode primer dan sekunder. Secara umum, survey data yang dilakukan adalah survey sekunder, melalui studi literatur pada beberapa instansi pemerintahan, seperti Badan Pusat Statistik Kota Bekasi, Badan Pusat Statistik Kota Bekasi, Badan Perencanaan Pembangunan Daerah Kota Bekasi, serta Dinas Tata Ruang Kota Bekasi. Kedalaman unit wilayah penelitian yang diambil mencakup kecamatan di seluruh Kota Bekasi.

B. Metode Analisis

1. Menentukan faktor faktor pengukuran urban compactness Kota Bekasi

Analisis ini terbagi dalam dua tahap yaitu analisis statistik kuantitatif dan analisis regresi lineaer berganda untuk menentukan faktor faktor yang terbukti signifikan dalam menerapkan kota kompak di Kota Bekasi. Melalui Uji Regresi Linear Berganda menggunakan metode stepwise dimana 10 variabel menjadi variabel independen diuji terhadap variabel Urban Compactness sebagai variabel dependent.

2. Mengukur Tingkat urban compactness berdasarkan faktor faktor nya di Kota Bekasi

Dalam metode ini, semua variabel yang dimiliki oleh setiap unit kecamatan didata dan disusun dalam suatu tabel. Untuk menentukan nilai tingkat pengukuran urban compactness maka digunakan metode Sturges. 
3. Memetakan pola spasial urban compactness di Kota Bekasi berdasarkan tingkatan faktor faktor urban compactness

Metode weighted overlay, metode analisis ini merupakan analisis spasial dengan menggunakan teknik overlay beberapa peta yang berkaitan dengan faktorfaktor yang berpengaruh terhadap penilaian urban compactness. Alat analisis yang digunakan adalah dengan menggunakan Geographic Information System (GIS)

4. Menganalisis strategi penerapan kota kompak di Kota Bekasi berdasarkan pola spasial Urban Compactness Analisis pada sasaran ini menggunakan analisis Deskriptif Komparatif dimana membandingkan tipologi yang dihailkan pada sasaran 3 satu sama lain untuk mendapatkan strategi penerapan kota kompak dari nilai variabel yang kurang pada masing masing pola spasial Urban Compactness di Kota Bekasi.

\section{HASIL DAN PEMBAHASAN}

A. Faktor faktor pengukuran urban compactness di Kota Bekasi

1. Analisis Statistik Kuantitatif

Analsis Statistik Kuantitatif digunakan untuk menghitung satuan nilai dari setiap variabel. Dimana setiap variabel mempunyai sub variabel yang berbeda beda untuk menentukan tiap jumlah variabel.

Tabel 1.

Variabel Input Penelitian

\begin{tabular}{ll}
\hline $\begin{array}{l}\text { Indikator } \\
\text { Penelitian }\end{array}$ & Variabel Input Penelitian \\
\hline Kepadatan & $\begin{array}{l}\text { Kepadatan Penduduk } \\
\text { Kepadatan Lahan Terbangun } \\
\text { Kepadatan Permukiman }\end{array}$ \\
& $\begin{array}{l}\text { Presentase Perubahan Kepadatan Terbangun } \\
\text { Fungsi }\end{array}$ \\
Pampuran & $\begin{array}{l}\text { Presentase luas Konsentrasi Permukiman } \\
\text { Terbangun } \\
\text { Ketersediaan Fasilitas }\end{array}$ \\
& Presentase Pertumbuhan Kepadatan \\
& Penduduk \\
Intensifikasi & \\
& Presentase Pertumbuhan Permukiman Baru \\
Indeks Urban Compactness \\
Compactness
\end{tabular}

2. Analisis Regresi Linear Berganda

Analisis Regresi Linear Berganda pada penelitian ini menggunakan metode stepwise. Dengan Variabel Terikat yang digunakan adalah Urban Compactness. Model persamaan analsisi ini dijalankan menggunakan software SPSS versi 23. Berikut ini merupakan model regresi yang menginterpretasikan faktor-faktor yang mempengaruhi ukuran urban compactness Kota Bekasi secara signifikan dengan model:

$\mathrm{Y}=6.405 \times 10^{-17}+0.666(\mathrm{X} 2)+0.312(\mathrm{X} 1)+0.244(\mathrm{X} 3)+$

$$
0.143(\mathrm{X} 5)
$$

\section{Keterangan:}

$\mathrm{Y}=$ Nilai urban compactness Kota Bekasi

$\mathrm{X} 1$ = Kepadatan Lahan Terbangun

$\mathrm{X} 2$ = Kepadatan Permukiman

$\mathrm{X} 3$ = Presentase Kepadatan Luas Terbangun
$\mathrm{X} 5=$ Ketersediaan Fasilitas Komersial

Berdasarkan model regresi yang dihasilkan terdapat empat faktor yang mempengaruhi ukuran urban compactness Kota Bekasi yaitu Kepadatan Permukiman, Kepadatan Lahan Terbangun, Presentase Perubahan Kepadatan Terbangun, Ketersediaan Fasilitas Perniagaan. Keempat Variabel tersebut mampu menjelaskan nilai urban compactness Kota Bekasi dengan presentase sebesar $78 \%$ (nilai R square terdapat pada lampiran B). Variabel lain tidak diakomodasi pada model regresi, terkait dengan nilai signifikansi yang tidak sesuai dengan nilai probabilitas F $0,05-0,1$. Hal ini memperlihatkan bahwa variabel-variabel tersebut belum secara signifikan mempengaruhi tinggi rendahnya ukuran urban compactness di Kota Bekasi.

\section{B. Mengukur tingkat urban compactness berdasarkan} faktor faktor nya di Kota Bekasi

Klusterisasi dilakukan dengan cara menjumlahkan nilai masing masing variabel serta melakukan overlay pada software arcgis. Hal ini diperuntukan agara pola keompakan masing masing kecamatan lebih terlihat dan terukur. Tabel nilaii masing masing kecamatan berdasarkan faktor nya adalah sebagai berikut:

Tabel 2.

Nilai Variabel Kekompakan

Menurut Masing Masing Kecamatan

\begin{tabular}{lllll}
\hline \hline Kecamatan & A & B & C & D \\
\hline Bekasi Utara & 5 & 5 & 3 & 4 \\
Bekasi Timur & 5 & 5 & 4 & 1 \\
Bantargebang & 3 & 1 & 4 & 2 \\
Bekasi Barat & 3 & 4 & 5 & 1 \\
Pondokgede & 3 & 5 & 5 & 1 \\
Bekasi Selatan & 2 & 5 & 3 & 3 \\
Jatiasih & 2 & 4 & 1 & 5 \\
Rawalumbu & 2 & 4 & 4 & 1 \\
Mustika Jaya & 2 & 1 & 2 & 3 \\
Medansatria & 2 & 4 & 1 & 1 \\
Pondok Melati & 2 & 1 & 3 & 1 \\
\hline \hline Jatisampurna & 1 & 1 & 4 & 1 \\
\hline Sumber Aisyah, & & & & \\
\hline
\end{tabular}

Sumber: Aisyah, 2017

Keterangan:

A : Nilai Kepadatan Permukiman

B : Nilai Kepadatan Terbangun

C : Nilai Konsentrasi Terbangun

D : Nilai Ketersediaan Fasilitas Perniagaan

C. Memetakan pola spasial urban compactness di Kota Bekasi berdasarkan tingkatan faktor faktor urban compactness

Klasifikasi pola spasial urban compactness di Kota Bekasi bertujuan untuk mengelompokan Ke-12 Kecamatan di Kota Bekasi menjadi kluster seperti yang sudah dilakukan pada analisis sebelumnya yang diharapkan dapat merepresentasikan urban compactness di Kota Bekasi berdasarkan ke empat faktor yaitu kepadatan permukiman, 
kepadatan lahan terbangun, konsentrasi lahan terbangun, serta ketersediaan fasilitas perniagaan.

Tabel 3.

Total Nilai Variabel dan Pengelompokan Kelas Klusterisasi Kekompakan

\begin{tabular}{lcc}
\hline \hline Kecamatan & Total & KLUSTER \\
\hline Bekasi Utara & 17 & I \\
Bekasi Timur & 15 & I \\
Pondokgede & 14 & II \\
Bekasi Barat & 13 & II \\
Bekasi Selatan & 13 & III \\
Jatiasih & 12 & III \\
Rawalumbu & 11 & III \\
Bantargebang & 10 & IV \\
Mustika Jaya & 8 & V \\
Medansatria & 8 & V \\
Pondok Melati & 7 & V \\
Jatisampurna & 7 & V \\
\hline \hline Sumber: Aisyah, & & \\
\hline
\end{tabular}

Sumber: Aisyah, 2017

Analisis ini menggunakan analisis overlay arcgis. Input peta adalah peta pola kepadatan permukiman, peta pola kepadatan terbangun, peta pola konsentrasi luas lahan terbangun, serta pola ketersediaan perbelanjaan. Metode ini digunakan sebagai metode yang secara langsung dapat memvisualkan pola spasial urban compactness di Kota Bekasi.

Hasil Visualisai Pola Spasial Urban Compactness dapat dilihat pada Gambar 1

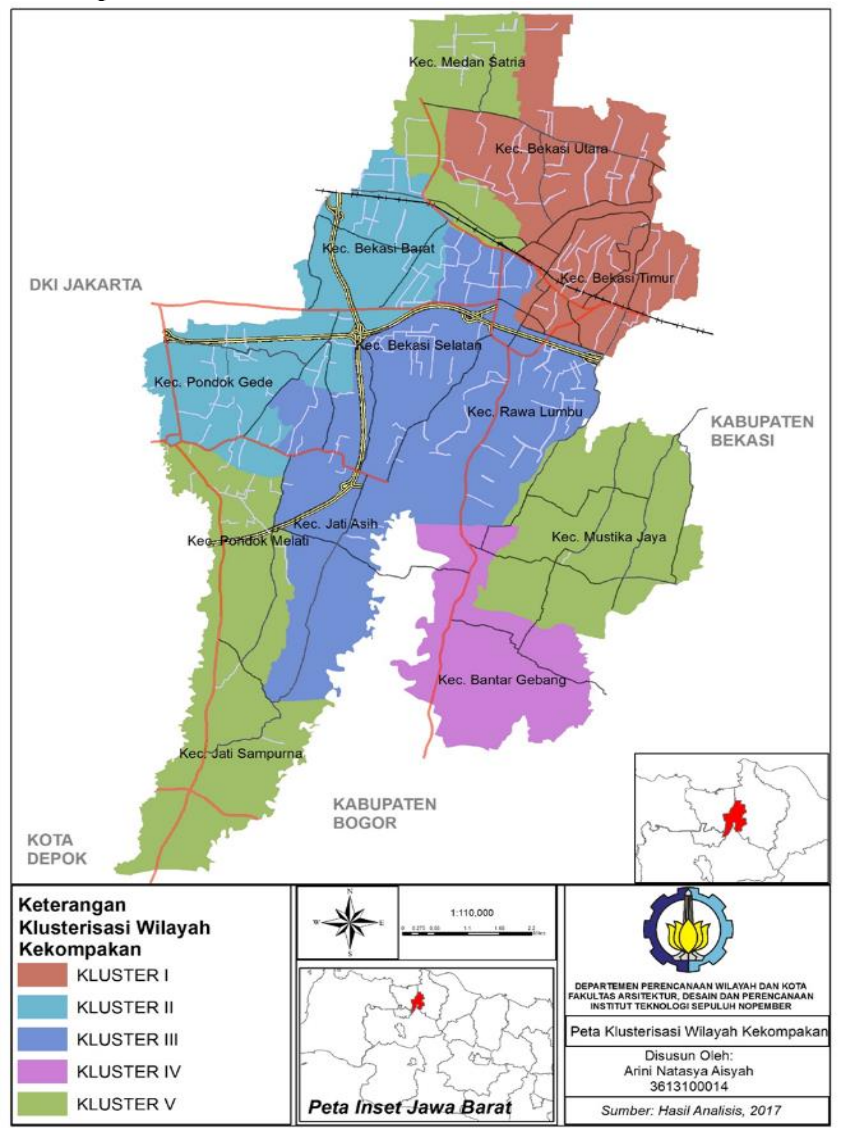

Gambar 1. Hasil Pola Spasial Urban Compactness Kota Bekasi.
D. Merumuskan strategi penerapan kota kompak di Bekasi berdasarkan pola spasial Urban Compactness

Berdasarkan hasil output analisis overlay arcgis dapat dilihat bahwa kluster kekompakan Kota Bekasi dibagi kedalam 5 kluster. Identifikasi keanggotaan tiap kluster klasifikasi pola spasial urban compactness Kota Bekasi adalah Sebagai Berikut:

Tabel 4.

Strategi Penerapan Kota Kompak Berdasarkan Kecamatan dan Kluste

\begin{tabular}{|c|c|c|}
\hline Kecamatan & Kluster & Strategi \\
\hline Bekasi Utara & \multirow[t]{2}{*}{ I } & $\begin{array}{l}\text { 1. Peningkatan Pembangunan dan } \\
\text { membudayakan pembangunan } \\
\text { hijau. } \\
\text { 2. Diterapkan batasan kepadatan } \\
\text { maksimum. Dengan disentif } \\
\text { apabila penduduk yang } \\
\text { mendaftar atau berpindah } \\
\text { melebihi batas maksimum maka } \\
\text { perizinan administrasi } \\
\text { kependudukan nya akan lebih } \\
\text { dipersulit. }\end{array}$ \\
\hline Bekasi Timur & & $\begin{array}{l}\text { 3. Peningkatan Pembangunan } \\
\text { Fasilitas Perniagaan untuk } \\
\text { mememuhi Self Sufficiency. }\end{array}$ \\
\hline Pondokgede & II & $\begin{array}{l}\text { 1. Pemanfaatan konsep Mixed Use } \\
\text { Zoning. } \\
\text { 2. Pembatasan kepadatan } \\
\text { maksimum dan minimum yang } \\
\text { sesuai dengan masing masing } \\
\text { kecamatan. }\end{array}$ \\
\hline Bekasi Selatan & \multirow{2}{*}{ III } & $\begin{array}{l}\text { 1. Pembangunan harus disertai } \\
\text { dengan konsep lingkungan. } \\
\text { 2. Pemanfaatan konsep Mixed Use } \\
\text { Zoning dengan mengubah } \\
\text { Konsep struktur Single Use } \\
\text { Zoning }\end{array}$ \\
\hline Rawalumbu & & $\begin{array}{l}\text { 3. Penambahan pusat pusat aktivitas } \\
\text { atau kegiatan yang dapat di } \\
\text { bangun untuk mentrigger konsep } \\
\text { Single Use Zoning menjadi } \\
\text { Mixed Use Zoning. } \\
\text { 4. Penerapan kebijakan kebijakan } \\
\text { minimum kepadatan. }\end{array}$ \\
\hline Bantargebang & IV & $\begin{array}{l}\text { 1. Konsep Pembangunan Mixed Use } \\
\text { Building dengan memperhatikan } \\
\text { Lingkungan. } \\
\text { 2. Penerapan kebijakan kebijakan } \\
\text { minimum kepadatan } \\
\text { 3. Penumbuhkan banyak kegiatan } \\
\text { kegiatan yang dapat menjadi } \\
\text { pemicu kepadatan aktivitas. }\end{array}$ \\
\hline Mustika Jaya & \multirow{3}{*}{ V } & $\begin{array}{l}\text { 1. Diperlukan struktur kota yang } \\
\text { berkonsep Mixed Use Zoning. } \\
\text { 2. Penerapan kebijakan kebijakan } \\
\text { minimum kepadatan dengan }\end{array}$ \\
\hline Medansatria & & $\begin{array}{l}\text { menumbuhkan banyak kegiatan } \\
\text { kegiatan. } \\
\text { 3. Apabila struktur Mixed Use } \\
\text { Zoning telah terbentuk } \\
\text { pembangunan selanjutnya adalah } \\
\text { penerapan konsep Mixed Use }\end{array}$ \\
\hline Pondok Melati & & Building. \\
\hline
\end{tabular}

Sumber: Aisyah, 2017

\section{KESIMPULAN}

Kesimpulan dari penelitian ini adalah:

1. Pengukuran terhadap tingkat urban compactness di Kota Bekasi mencakup nilai, kelas, pola spasial, serta 
karakteristik urban compactness masing masing kecamatan yang dihasilkan menjadi 5 kluster dengan karakteristik yang berbeda beda.

2. Terdapat empat kecamatan atau dua kluster yang telah memenuhi unsur unsur kekompakan menurut pengukuran kekompakan kota Bekasi, yaitu kluster I (Kecamatan Bekasi Timur damKecamatan Bekasi Utara) dan Kluster II (Pondok Gede dan Bekasi Barat).

3. Terdapat dua kluster yang memiliki potensi dalam membentuk struktur kompak yaitu kluster III dan Kluster IV.

4. Kluster V merupakan kluster dengan kecenderungan sprawl.

5. Strategi yang dapat dilakukan adalah penerapan kebijakan kepadatan maksimum dan minimum, intensifikasi penggunaan Mixed Use Zoning serta pembangunan konsep Mixed Use Building.

\section{DAFTAR PUSTAKA}

[1] I. P. Praditya, "Faktor-Faktor Pengaruh Ukuran Urban Compactness di Kota Denpasar, Bali,” Institut Teknologi Sepuluh Nopember, 2015.

[2] I. dkk Kustiwan, "Pengukuran Compactness Sebagai Indikator Keberlanjutan Kota dan Kebutuhan Pengembangan Compact City pada Kawasan Tumbuh Pesat di Indonesia," SAPPK-ITB Res. Ser., vol. 3, 2007.

[3] A. N. Aisyah, "Strategi Penerapan Kota Kompak Berdasarkan Pola Urban Compactness di Kota Bekasi,” Institut Teknik Sepuluh Nopember, 2017.

[4] Z . Mahriyar, "PERUMUSAN KONSEP PENINGKATANEFEKTIVITAS URBAN COMPACTNESS DI KOTA SURABAYA," Institut Teknologi Sepuluh Nopember, 2010. 